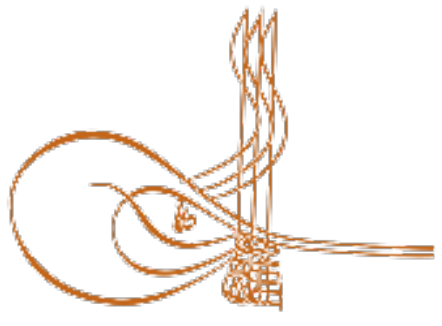

www.turkishstudies.net/education
Turkish Studies - Educational Sciences

eISSN: $2667-5609$

Research Article / Araștırma Makalesi

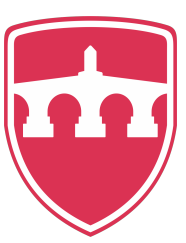

INTERNATIONAL

BALKAN

UNIVERSITY

Sponsored by IBU

\title{
Sosyal Bilgiler Alanı Öğretim Programlarına Ait Kazanımların Zihinsel Beceriler Temelinde Gösterdiği Dağılımın İncelenmesi ${ }^{1}$
}

Outcomes Social Studies Curriculum Based on Thinking Skills

\author{
Emel Bayrak Özmutlu*
}

\begin{abstract}
In this research, it is aimed to examine the distribution of the outcomes in the curriculum of the life studies, social studies and history of revolution and Kemalism courses on the basis of thinking skills. The document analysis method, which is included in the qualitative research model, was adopted. In this research, all of the 318 outcomes in the social studies curriculum were examined. In the data analysis process of the research, an intense analysis process consisting of three steps using repeated reading, coding and continuous comparison method was followed. The curriculum is available on the official website of the Ministry of National Education. The findings of the research show that the outcomes of social studies curriculum aim to develop 22 different thinking skills. Life studies course aims to develop 15 different thinking skills. Social studies course aims to develop 21 different thinking skills. T.C. History of Turkish Revolution and Kemalism course aims to develop nine different thinking skills. It is seen that the thinking skill which is aimed to develop at most is the application while the thinking skill which is aimed to be developed at least is problem solving. Educational scientists need to focus on the possibilities that their curriculum has in developing thinking skills. It is necessary to examine which thinking skills the curriculum excludes in this state, which one gives too much weight, what possibilities it does not take into consideration, and in the light of these examinations, necessary arrangements must be made in the social studies curriculum.
\end{abstract}

Structured Abstract: Introduction This research aims to examine the outcomes of the curricula on life studies, social studies, history of revolution, and Kemalism, which are focused on using thinking skills. Accordingly, the answers to the following questions were sought: How does thinking skills, which are aimed at developing the outcomes of the social studies curriculum, distributed by class? How is thinking skills distributed in accordance with the course and learning areas/units? In this study, the thinking skills that the students intend to develop through studies conducted on the basis of social studies curriculum outcomes for eight years are examined. In addition, the distribution of thinking skills in lessons and learning area/units is examined. Through this examination, the extent to which the thinking skills are intended to be developed with

\footnotetext{
${ }^{1} \mathrm{Bu}$ araştırmanın bir bölümü 19-22 Haziran 2019 tarihleri arasında düzenlenen VII ${ }^{\text {th }}$ International Eurasian Educational Research Congress/ 7. Uluslararası Avrasya Eğitim Araştırmaları Kongresi'nde sunulmuştur.

*Dr. Öğr. Üyesi, Ordu Üniversitesi, Eğitim Fakültesi, Temel Eğitim Bölümü

Asts. Prof., Ordu University, Education Faculty, Basic Education Department

ORCID0000-0002-1222-3557

emelozmutlu@odu.edu.tr

Cite as/ Atıf: Bayrak Özmutlu, E. (2020). Sosyal bilgiler alanı öğretim programlarına ait kazanımların zihinsel beceriler temelinde gösterdiği dağılımın incelenmesi, Turkish Studies - Education, 15(1), 15-32 https://dx.doi.org/10.29228/TurkishStudies.40359

Received/Geliş: 30 December/Aralık 2019

Accepted/Kabul: 25 February/Şubat 2020

Copyright à INTAC LTD, Turkey

Checked by plagiarism software

Published/Yayın: 29 February/Subat 2020

CC BY-NC 4.0
} 
outcomes that are compatible with the courses and learning areas is identified. This study will provide guidance for the development of high-quality curricula on the development of thinking skills.

\section{Literature Review}

The developments in the 21 st century have led to changes in the individual qualities needed in society. These changes have urged educational institutions to develop students' high-level thinking and in-depth learning skills (Kutlu, Doğan and Karakaya, 2010; Senemoğlu, 2011). The updated social studies curriculum is a structure that directs students to use high-level thinking skills, provides meaningful and permanent learning, associates solid and previous learning, and integrates values, skills, and competences with other disciplines and daily life (Ministry of National Education [MEB], 2018). However, the extent on how the emphasis on thinking skills are emphasized in the purpose and structure of the curriculum is reflected in the curriculum outcomes is unknown. A thinking skill that is not found in the curriculum outcomes will also not be included in the teaching activities and, therefore, in the learning outcomes. Thus, it is of great importance to examine how outcomes are reflected in the thinking skills that the curriculum aims to develop. A number of researchers have examined the relationship between achievement and value in the social studies course curriculum (Tonga and Uslu, 2015) and the revolutions of the Turkish revolution history and Kemalism curriculum in accordance with the renewed Bloom taxonomy (Gezer, Şahin, Sünkür and Meral, 2014). Some studies have also examined the curriculum of social studies based on the opinions of teachers (Taş and Kıroğlu, 2017; Öztürk, 2015; Memişoğlu and Köylü 2015; Öztürk and Kalafatçı, 2015; Tangülü, Tosun and Kocabıyık, 2014). Furthermore, other studies have analyzed previous and current curricula using curriculum components (Tay and Baş, 2015; Çaban and Aksit, 2018; Koçoğlu and Aydın, 2018). In the literature, no recent study has examined the social studies curriculum outcomes from grades 1-8 and examined the distribution of outcomes according to thinking skills. In this respect, the present research is expected to fill such a deficiency in the literature.

\section{Method}

In the research, the document analysis method, which a qualitative research method, was adopted. A criterion sampling type, a purposeful sampling type, was also used. The study group of the research consists of 318 outcomes of the curriculum of life studies, social studies, history of the Turkish Revolution, and Kemalism course. The can be accessed on the official webpage of the Ministry of National Education, which came into force in 2018. In the data analysis process of the research, an intensive analysis process, which consisted of three steps, namely, repeated reading, coding, and continuous comparison, was followed.

\section{Findings and Discussion}

A total of 22 different thinking skills were aimed to be developed through the social studies curriculum. The most developed thinking skill in the curriculum is the application thinking skills, whereas the least developed thinking skill is problem solving. The research shows that the outcomes aimed at developing the questioning, problem-solving, evaluation, and innovative thinking skills are very low. Such findings are similar to those of other studies in the literature (Öztürk, 2015; Demir, Tutkun, Şahin, and Genç, 2014). On the basis of levels, the ratio of high-level thinking skills is $50.2 \%$. Similar studies seem to confirm this finding (Aydemir and Adamaz, 2017; Gazel and Erol, 2012; Gezer, Şahin, Öner-Sünkür and Meral, 2014). The research shows that nearly half of the curriculum outcomes aim to improve the thinking skills of practice, remembering, analyzing, and decision making. Similar findings can be seen in recent studies on social studies curriculum (Çoban ve Aksit, 2018). The research findings also point out that the thinking skills that the objectives aim to develop do not have a proportional distribution among themselves and on the basis of levels.

\section{Conclusion and Suggestions}

In the 21 st century, the importance of thinking skills is continually increasing. In this paper, a description of the current situation of the curriculum outcomes of grades 1-8 as regards developing thinking skills in the field of social studies is presented. The research shows that the social studies curriculum aims to develop 22 different thinking skills. A closer look at the research findings reveals that the thinking skills that rank in the top four correspond to about half of the outcomes. The findings of the study show that the diversity of thinking skills in the curriculum is not reflected equally in the whole program. Furthermore, the findings reveal that the thinking skills with lowest rates are questioning, problem solving, evaluation, and innovative thinking. The ratio of these thinking skills in the program outcomes, structure, and reasons should be increased. Moreover, skills do not show an increase or decrease on the basis of class levels. This finding suggests that the

Turkish Studies - Education, 15(1) 
development of thinking skills is not considered in a planned manner. In order for schools to educate individuals the potential of subject areas in developing thinking skills should be utilized at the highest level during the curriculum development process. Decision-makers need to focus on how thinking skills should be emphasized or excluded from the social studies curriculum, as indicated by the research findings.

Keywords: Curriculum Development, Thinking Skills, 21.Century Skills, Social Studies Teaching, Social Studies Teaching Curriculum.

Öz: Bu araştırma hayat bilgisi, sosyal bilgiler ve T.C. İnkılap Tarihi ve Atatürkçülük derslerine ait öğretim programlarında yer alan kazanımların geliştirmeyi amaçladığı zihinsel beceriler temelinde gösterdiği dağılımı incelemeyi amaçlamaktadır. Araştırmada nitel araştırma modeli içinde yer alan doküman incelemesi yöntemi benimsenmiştir. Araştırmada 1-3. sınıf hayat bilgisi, 4-7.sınıf sosyal bilgiler ve 8.sınıf T.C. İnkılap tarihi ve Atatürkçülük derslerine ait sosyal bilgiler alanı öğretim programlarında yer alan +318 kazanımın tamamı incelenmiştir. Araştırmanın veri analizi sürecinde tekrarlı okuma, kodlama ve sürekli karşılaş̧ırıma yönteminin kullanıldığı üç adımdan oluşan yoğun bir analiz süreci takip edilmiştir. Araştırma bulguları sosyal bilgiler alanı öğretim programları kazanımlarının 22 farklı zihinsel beceriyi geliştirmeyi amaçladığını göstermektedir. Sosyal bilgiler alanı öğretim program kazanımlarının geliştirmeyi amaçladığı zihinsel becerilerinin derslere göre dağıllmı incelendiğinde hayat bilgisi dersi ile 15; sosyal bilgiler dersi ile 21, T.C. İnkılap Tarihi ve Atatürkçülük ders ile dokuz zihinsel becerinin geliştirilmesinin amaçlandığı görülmektedir. Sosyal bilgiler alanı öğretim programlarında yer alan kazanımların en fazla geliştirmeyi amaçladığı zihinsel beceri uygulama iken en az geliştirilmesi amaçlanan zihinsel becerinin problem çözme olduğu görülmektedir. Bunun yanında sorgulama, değerlendirme ve yenilikçi düşünme zihinsel becerilerini geliştirmeyi amaçlayan kazanımların incelenen öğretim programlarındaki oranlarının oldukça düşük olduğu görülmüştür. Eğitim bilimcilerinin sosyal bilgiler alanının zihinsel becerileri geliştirme konusunda sahip olduğu potansiyeller üzerinde bilimsel çalışmalar yürütmesi önemli bir gerekliliktir. Bununla birlikte söz konusu araştırma bulgularının program geliştirme sürecinde dikkate alınması büyük önem taşımaktadır. Öğretim programlarının bu haliyle hangi zihinsel becerileri dışarıda bıraktığı, hangisine fazlaca ağırlık verdiği, hangi olasılıkları dikkate almadığının incelenmesi ve bu incelemeler ışığında sosyal bilgiler alanı öğretim programlarında gerekli düzenlemelerin yapılmas1 gerekmektedir.

Anahtar Kelimeler: Program Geliştirme, Zihinsel Beceriler, 21.Yüzyıl Becerileri, Sosyal Bilgiler Öğretimi, Sosyal Bilgiler Öğretimi Programı

\section{Giriş}

21.yüzy1lda yaşanan gelişmeler bireylerden, üst düzey düşünme becerilerini etkili olarak kullanmalarını talep etmektedir. Bu talep okullardan beklenenler üzerinde değişim yaşanmasına neden olmaktadır. Eğitimden bağımsız düşünen, karar alan, problemleri yaratıcı yollarla çözen bireyler yetiştirmesi beklenmektedir (Klimova, 2012). Bilgiye erişimin çok kolay oluşu nedeniyle bilgiye eleştirel bakabilme, diğer kaynaklarla karşılaştırma yapabilme, bilginin doğruluğu hakkında karar verebilme becerilerine sahip olmak önem kazanmaktadır (Göksün ve Kurt, 2017). Bu nedenle okulların öğrencilere doğrudan bilgi vermek yerine onların bilgiyi anlamlandırma, kullanma, önemli olan bilgi ile önemsiz olanı ayırt etme ve öğrendiklerini gerçek yaşam durumları ile ilişkilendirme becerilerini geliştirmesi gerektiğinin altı çizilmektedir (Harari, 2018). Okulların geleceğin dünyasının gerekliliklerini yerine getirebilmelerinde, zihinsel becerileri geliştirme konusundaki başarısının önemli bir rol oynadığı görülmektedir.

Okullarda zihinsel becerilerin önem kazanmasında zekâ ve yeteneğin tanımlanma biçiminin değişmiş olması da etkili olmuştur. Zekâ bugün bir takım üst düzey öğrenme süreçleri ile gelişebilen bir olgu olarak görülmektedir (Diveck ve Molden, 2005). Bu bakış açısı, üst düzey zihinsel becerileri geliştirmeye yönelik uygulamalarla bireyin zekâ ve yeteneklerinde gelişim sağlamanın mümkün olduğu anlamına gelmektedir. Söz konusu durum okullara, öğrencilerin zekâ ve yeteneklerini en üst düzeye taşıma sorumluluğu yüklemektedir. Zekâ ve öğrenme konusunda yaşanan bu değişim, düşünme programı (thinking curriculum) adı verilen bir program formunda kendini göstermektedir 
(Resnick, 1987; 2010; Resnick ve Klopfer, 1989). Türkiye'de 2005 yılından bu yana geliştirilen öğretim programlarında zihinsel becerilerin öğretiminde benzer bir yaklaşımı görmek mümkündür.

Yukarıda kısaca açıklanan gelişmelerin etkisiyle 1980 sonrası tüm dünyada zihinsel becerilere yönelik çalışmaların hız kazandığı görülmektedir. Bu süreçte birbirinden farklı program yaklaşımları benimsenmiştir. Bu yaklaşımlar arasında, zihinsel becerileri öğretim programlarının içsel bir parçası olarak geliştirme, çok sayıda araştırmacı tarafından desteklenmektedir. Bu programlar, içeriğin zihinsel becerileri geliştirme konusunda sahip olduğu potansiyelden yararlanma olanağı tanımakta, zihinsel beceriyi içerik içinde uygulama şansı vererek becerinin transfer problemini ortadan kaldırmakta ve zihinsel becerinin öğretimi için ayrı bir zaman yaratma zorluğunun üstesinden gelmeyi sağlamaktadır. Resnick'in (1987) belirttiği gibi bu yaklaşım, üst düzey becerilerin uygulanacağı ve geliştirileceği doğal bir bilgi tabanı ve ortamı sağlamaktadır. 2018 yılında güncellenen sosyal bilgiler alanı öğretim programlarında her ders için ortak yeterlilik çerçevesi belirlendiği görülmektedir (T.C. Milli Eğitim Bakanlığı [MEB], 2018). Bunun yanında disipline özgü becerilerin kazanımlarla ilişkilendirildiği (MEB, 2017) iddia edilmektedir. İfade edilenler dikkate alındığında, sosyal bilgiler alanı öğretim programlarında zihinsel becerilerin öğretiminde benzer bir yaklaşımın benimsendiği söylenebilir.

Zihinsel beceri öğretiminde, becerileri düzeyler temelinde sınıflayan çalışmalar önemli bir yer tutmaktadır. Örneğin Beyer (1984), zihinsel becerileri temel beceriler ve üst düzey beceriler olarak sınıflandırmıştır. Temel becerileri tekil beceriler olarak ifade etmek mümkünken birden fazla temel becerinin birlikte kullanımını gerektiren beceriler üst düzey zihinsel beceriler olarak ifade edilmektedir. Bu beceriler arasında eleştirel düşünme, karar verme, problem çözme ve yaratıcı düşünme becerisi yer almaktadır. Benzer bir sınıflamanın görüldüğü gözden geçirilmiş Bloom'un Taksonomisi'nde ise alt düzey zihinsel beceriler hatırlama, anlama ve uygulama; üst düzey zihinsel beceriler ise analiz etme, değerlendirme ve yaratma olarak ifade edilmektedir (Anderson ve Krathwohl, 2001). Bu sınıflamaların dışında alan yazında zihinsel becerilerin sınıflandırılmasına yönelik çalışmaların olduğu görülmektedir (Bloom, 1956; Gagné ve Briggs, 1979; Haladayna, 1997; Marzano, 2001; Romizowski, 1981). Sınıflamalar program geliştirme çalışmalarının her aşamasında rehberlik edici bilgiler sunmaktadır.

Zihinsel beceri öğretimi kapsamında bir diğer gelişme 21. Yüzyıl becerileridir. Bu kapsamda yürütülen çalışmalar bireylere; bilgi ve iletişim teknolojileri okuryazarlığı, kişisel ve sosyal sorumluluk, işbirliği ve iletişim becerileri, üretkenlik, üst düzey düşünme, yaratıcılık, yenilikçilik, yaşam boyu öğrenme gibi becerilerin kazandırılması gerektiğini vurgulamaktadır (Bozkurt ve Çakır, 2016). 21. Yüzyıl becerileri ile ilgili olarak çeşitli kurum ve kuruluşlara ait sinıflamalar olduğu (NCREL [North Central Regional Educational Laboratory], P21 [Partnership for 21st Century Learning], ATCS [Assessment and Teaching of 21st Century Skills], ASIA Society [Asia Society Partnership for Global Learning], OECD [Organization for Economic Cooperation and Development], EU [European Union], ISTE [International Society for Technology in Education]) görülmektedir (Anagün, Atalay, Kılıç ve Yaşar, 2016). Sınıflamalar incelendiğinde yaratıcılık, eleştirel düşünme, problem çözme, nitelikli ürün oluşturma becerilerinin en fazla yer verilen beceriler arasında olduğu görülmektedir (Voogt ve Roblin, 2012).

Türkiye'de özellikle 2005 yılından bu yana geliştirilen öğretim programlarında zihinsel becerileri geliştirmeye yönelik çalışmaları görmek mümkündür. Örneğin 2005 yılına ait öğretim programlarının tamamında geleceğin becerileri temel beceriler olarak ifade edilmiştir. Bunlar araştırma, bilgi teknolojilerini kullanma, eleştirel düşünme, girişimcilik, iletişim kurma, problem çözme, Türkçeyi doğru, etkili ve güzel kullanma, yaratıcı düşünme, kişisel ve sosyal değerlere önem verme, karar verme olarak geçmektedir (MEB, 2005). 2018 yılında yenilenen sosyal bilgiler alanı öğretim programlarında Türkiye Yeterlilik Çerçevesi temelinde sekiz yetkinlik belirlenmiştir (MEB, 2018). Bunlar; anadilde iletişim, dijital yetkinlik, matematiksel yetkinlik ve bilim/teknolojide temel 
yetkinlikler, öğrenmeyi öğrenme, sosyal ve vatandaşlıkla ilgili yetkinlikler, inisiyatif alma, yabancı dillerde iletişim, girişimcilik ve kültürel farkındalık isimleriyle geçmektedir. Bunun yanında güncellenen öğretim programlarında sosyal bilgiler dersine özgü 27, hayat bilgisi dersine özgü 23 becerinin tablosuna yer verildiği görülmektedir.

Sosyal bilimler üst düzey düşünmenin en yoğun şekilde kullanıldığı alanlardan biridir. Çünkü bireylerin sosyal hayatlarında yüzleştiği sorunlara yönelik gözlem yapmayı, sorular geliştirmeyi ve sormayı, araştırma yapmayı, gözlem ve araştırmalarına dayalı fikirlerini çeşitli yollarla açıklamayı, bir takım bakış açıları temelinde tartışmayı ve eyleme geçmeyi mümkün kılmaktadır (Hayırsever ve Kısakürek, 2014). Sosyal bilgiler dersi, sosyal bilimlerin zihinsel becerileri geliştirme konusunda sahip olduğu olanaklardan yararlanma olanağına sahiptir. Öğrencilere sosyal ilişkileri ve vatandaşlık nitelikleri edindirmek amacıyla disiplinler arası bir anlayış içinde antropoloji, coğrafya, felsefe, hukuk, psikoloji, arkeoloji, ekonomi, siyaset bilimi, tarih ve sosyoloji gibi bilimlerin kaynaştırılmasıyla oluşturulmuştur. Bu ders ile bilgiyi üreten ve hayatta işlevsel olarak kullanabilen, problem çözebilen, eleştirel düşünen, girişimci, kararlı, iletişim becerilerine sahip, empati yapabilen, topluma ve kültüre katkı sağlayan vb. niteliklerdeki bireyler yetiştirmek amaçlanmaktadır (MEB, 2018). Sosyal bilgiler dersinin yapı ve özellikleri incelendiğinde, dersin amaçlarına öğrencileri üst düzey zihinsel becerilerinde gelişim sağlanarak ulaşılabileceği görülmektedir.

Sosyal Bilgiler alanına ait öğretim programları 2018 yılında güncellenmiştir. Güncellenen programda hükûmetlerin eylem planları, kalkınma planları, uluslararası çapta yapılan sınav sonuçları, çeşitli ulusal ve uluslararası düzeyde kurum ve kuruluşların hazırladığı raporlar ile bilimsel araştırma bulgularının dikkate alındığ ifade edilmektedir. Bunun yanında programın gerekçelerinin açıklandığ 18 Temmuz 2017 tarihli metinde şu ifadeler göze çarpmaktadır (MEB, 2017, 9-10):

\begin{abstract}
Yenilenen müfredatlar ile ögrencilere kazandırllması hedeflenen temel yeterlilik ve beceriler tüm disiplin alanlart için ortak olarak verilmiştir. Bu yeterlilik ve beceriler, müfredatlarda disiplin alanlarının kazanımlarına ve/veya açıklamalarına doğrudan yahut dolaylı olarak ilişkilendirilmiştir. 21. yüzyıl becerileri olarak adlandırılan ve yeni yüzyılın mezunlarının sahip olması beklenilen yeterlilik ve beceriler de kazanımların ve kazanım açıklamalarının yapılandırılmasında göz önünde bulundurulmuştur. Müfredatlarda disiplin alanlarına özgü yeterlilik ve becerilere yer verilmiştir.”
\end{abstract}

$\mathrm{Bu}$ açıklamalardan, sosyal bilgiler alanı öğretim programlarında zihinsel becerilerin programın içsel bir parçası olarak geliştirilmeye çalışıldığı görülmektedir.

Güncellenen öğretim programın yapısına ilişkin açıklamalar incelediğinde öğrencileri üst düzey zihinsel beceri kullanımına yönlendirme, anlamlı ve kalıcı öğrenmeyi sağlama, diğer disiplinlerle ve günlük hayatla değerler, beceriler ve yetkinlikler çevresinde bütünleşmiş olma özelliklerine sahip olduğu ifade edilmektedir (MEB, 2018). Program değişikliği gerekçelerinde, programın amaç ve yapısında zihinsel becerilere yapılan vurgunun program kazanımlarına hangi oranda yansıdığı merak edilmektedir. Alanyazın incelendiğinde sosyal bilgiler alanı öğretim programlarında kazanım ve değer ilişkisini (Tonga ve Uslu, 2015), kazanım beceri ilişsisini inceleyen (Taşkıran, 2014; Gezer, Şahin, Sünkür ve Meral, 2014) araştırmalar olduğu görülmektedir. Bunun yanında sosyal bilgiler alanı öğretim programlarını öğretmen görüşlerine dayalı olarak inceleyen çalışmaların (Memişoğlu ve Köylü, 2015; Öztürk, 2015; Öztürk ve Kalafatçı 2016; Tangülü, Tosun ve Kocabıyık, 2014; Taş, Kıroğlu, 2018) yanında; geçmiş yıllara ait ve güncel öğretim programlarını bir takım program öğeleri temelinde analiz eden (Çoban ve Akşit, 2018; Koçoğlu ve Aydın, 2017; Tay ve Baş, 2016) araştırmaları da görmek mümkündür. Alanyazında sosyal bilgiler alanı öğretim program kazanımlarını 1-8 sınıf temelinde ele alan ve güncel program kazanımlarını zihinsel beceriler temelinde inceleyen bir araştırmaya rastlanmamıştır. Araştırmanın bu açıdan alanyazında görülen bir eksikliği dolduracağı düşünülmektedir. 
Program kazanımlarında kendine yer bulamayan bir zihinsel becerinin öğretim etkinliklerinde ve dolayısıyla öğrenme çıktılarında kendine yer bulamayacağı düşünülmektedir. Bu açıdan kazanımların geliştirmeyi amaçladığı zihinsel beceriler temelinde nasıl bir görünüme sahip olduğunu incelemek büyük bir önem taşımaktadır. Araştırmada kazanımların sınıflara göre dağılımı incelenmiştir. Bu inceleme sayesinde sosyal bilgiler alanında sekiz yıl süresince program kazanımları temelinde yürütülen çalışmalarla öğrencilerde hangi zihinsel becerileri geliştirmenin olası olduğunu görmek mümkün olabilecektir. Bunun yanında araştırmada zihinsel becerilerin dersler ve öğrenme alanı/üniteler temelinde gösterdiği dağ $11 \mathrm{~m}$ incelenmektedir. Bu inceleme sayesinde kazanımlarla geliştirilmesi amaçlanan zihinsel becerilerin dersler ve öğrenme alanları ile hangi oranda uyumlu olduğunu görebilmek mümkün olacaktır. Bu araştırmanın zihinsel becerilerin gelişimi konusunda üst nitelikte öğretim programlarının geliştirilmesi sürecine rehberlik edici bilgiler sağlayacağı düşünülmektedir. Bu araştırmada hayat bilgisi, sosyal bilgiler ve T.C. İnkılap Tarihi ve Atatürkçülük derslerine ait öğretim programlarında yer alan kazanımların geliştirmeyi amaçladığı zihinsel beceriler temelinde incelenmesi amaçlanmaktadır. Araştırmanın amacı doğrultusunda, aşağıdaki sorularının cevabı aranmıştır:

Sosyal bilgiler alanı öğretim programlarında yer alan kazanımların geliştirmeyi amaçladığı zihinsel beceriler, sınıflara göre nasıl bir dağılım göstermektedir?

Sosyal bilgiler alanı ögretim programlarında yer alan kazanımların geliştirmeyi amaçladığı zihinsel beceriler ders, öğrenme alanına/ünitelere göre nasıl bir dağılım göstermektedir?

\section{Yöntem}

\section{Araştırmanın Modeli}

Bu araştırmada 2018 y1lında güncellenen hayat bilgisi, sosyal bilgiler ve T.C. İnkılap Tarihi ve Atatürkçülük dersi öğretim programlarında yer alan kazanımların, geliştirmeyi amaçladığı zihinsel beceriler temelinde nasıl bir dağılım gösterdiğini incelemek amaçlanmıştır. Araştırma amaçları doğrultusunda, çalışma kapsamına dâhil edilen program dokümanlarında yer alan kazanımlar üzerinde bir incelemenin yürütülmesi gerekmektedir. Bu nedenle bu araştırma doküman inceleme yöntemi ile gerçekleştirilmiştir. Nitel araştırma yöntemlerinden biri olan doküman inceleme yöntemi, araştırma amacı ile ilgili olgulara ait bilgilerin yer aldığı dokümanların incelenmesi ve analiz edilmesi olarak tanımlanmaktadır (Yıldırım ve Şimşek, 2011). Bu araştırmada 2018 yılında yürürlüğe giren ve Milli Eğitim Bakanlığının resmi internet sayfasından ulaşılabilen sosyal bilgiler alanı öğretim programları incelenmiş ve analiz edilmiştir. Bu açıdan araştırmada doküman incelemesi yöntemini kullanmanın uygun olduğu düşünülmüştür.

\section{Çalışma Kapsamı}

Araştırmanın çalışma kapsamı belirlenirken ölçüt örnekleme yöntemi ile belirlenmiştir. Ölçüt örnekleme yöntemi belli ölçütleri sağlayan tüm durumların seçimi (Baltacı, 2018) olarak tanımlanmaktadır. Araştırma örnekleminin seçiminde; öğretim programlarının ilkokul ve ortaokul düzeyinde olması, Türkiye'de yürürlükte olan programlar olması ve sosyal bilgiler alanına ait olması ölçütleri belirlenmiştir. Araştırmanın çalışma kapsamını, 2018 yılında yürürlüğe giren ve Milli Eğitim Bakanlığını resmi internet sayfasında erişime açık olup elektronik olarak ulaşılabilen hayat bilgisi, sosyal bilgiler ve TC İnkılap Tarihi ve Atatürkçülük dersi öğretim programlarında yer alan toplam 318 kazanım oluşturmaktadır. Kazanımların derslere ve sınıflara göre dağılımı Tablo 1.'de görülmektedir. 
Sosyal Bilgiler Alanı Öğretim Programlarına Ait Kazanımların Zihinsel Beceriler Temelinde... 21

Tablo 1: Araştırmanın Çalışma Kapsamını Oluşturan Kazanımların Sınıf ve Dersler Temelinde Gösterdiği Dağılım

\begin{tabular}{|c|c|c|c|c|c|c|c|c|}
\hline \multicolumn{3}{|c|}{ Hayat Bilgisi } & \multicolumn{4}{|c|}{ Sosyal Bilgiler } & \multicolumn{2}{|l|}{ T.C. İnkılap } \\
\hline & & & & & & & Atatürkcülük & Toplam \\
\hline 1.sInıf & 2.sınıf & 3.sinıf & 4.sinıf & 5.sinıf & 6.sinıf & 7.sinıf & 8.sınıf & \\
\hline 53 & 50 & 45 & 33 & 33 & 34 & 31 & 39 & 318 \\
\hline \multicolumn{3}{|c|}{148} & & 131 & & & 39 & 318 \\
\hline
\end{tabular}

\section{Verilerin Analizi}

Araştırmanın veri analizi sürecinde tekrarlı okuma, kodlama ve sürekli karşılaştırma yönteminin kullanıldığı üç adımdan oluşan yoğun bir analiz süreci takip edilmiştir.

1.Adım. Kazanımların elektronik ortama taşınması. Araştırmanın analiz sürecinde hayat bilgisi, sosyal bilgiler ve T.C. İnkılap tarihi ve Atatürkçülük derslerine ait 3 sosyal bilgiler alanı öğretim programına ait 318 kazanımın tamamı elektronıik ortamda üç sütunlu bir tablo içine yerleştirilmiş̧tir.

2.adım. Kazanımların kodlanması. Analizin bu aşamasında her kazanım tekrarlı olarak okunarak kazanımın hangi zihinsel beceriyi geliştirmeyi amaçladığına karar verilmiştir. Bu süreçte üç sütunlu bir tablo kullanılmıştır. Tablonun ilk sütununda kazanım, ikinci sütununda kazanımın geliştirmeyi amaçladığına karar verilen zihinsel beceri, üçüncü sütunda ise neden kazanımın bu zihinsel beceri ile kodlandığına ilişkin açıklamalar yer almaktadır. Analiz sürecinde incelenen kazanımın geliştirmeyi amaçladığına karar verilen zihinsel becerinin ne olduğu ikinci kutucuğa yazılmıştır. İlgili kazanımın neden bu zihinsel beceri ile kodlandığına ilişkin açıklama ise üçüncü kutucuğa yazılmıştır. Bu açıklamalar, kodlayıcılar arası uyuma ilişkin değerlendirme sürecinde kullanılmıştır. Kazanımları kodlama ve kod gerekçelerini açıklama işlemi 318 kazanımın tamamı için uygulanmıştır. Analizin bu aşaması iki araştırmacı tarafından bağımsız bir şekilde gerçekleştirilmiştir.

3.adım. Kazanımların sınıflandırılması ve özetlenmesi. Kodlama işleminin ardından oluşturulan tabloda yer alan kazanımlar sınıf, dersler, öğrenme alanı/üniteler temelinde sınıflandırılmıştır. Zihinsel becerilerin sınıf ve derslere göre gösterdiği dağılım, betimleyici istatistiklerden yararlanarak özetlenmiş̧ir. $\mathrm{Bu}$ analiz sonrasında araştırma problemlerine cevap verilmişstir.

\section{Geçerlilik ve Güvenirlik Çalışmaları}

Nitel araştırma yönteminin benimsendiği bu araştırmada geçerlilik ve güvenirlik çalışmaları kapsamında aşağıdaki çalışmalar yürütülmüştür. Nitel araştırmalarda geçerlilik ve güvenirlik çalışmalarından biri olan inandırıcılık, toplanan verilerin doğruluğu ve inandırıcılığı anlamına gelmektedir (Güler, Halıcıoğlu ve Taşgın, 2013). Bu araştırmanın verilerini, 2018 yılında yürürlüğe girmiş olan, sosyal bilgiler alanı öğretim programlarında yer alan kazanımlar oluşturmaktadır. Araştırma kapsamında analiz edilen veriler, Milli Eğitim Bakanlı̆̆ının resmi internet sayfasında yayınladığı şekliyle alınmıştır. Bu açıdan araştırmada incelenen verilerin inandırıcılık gerekliliğini sağladığı söylenebilir. Nitel araştırmalarda inandırıcılık gerekliliği için çalışma grubunun sayı, özellik ve seçim bilgilerinin paylaşılması gerekmektedir. Bunun yanında araştırma kapsamında kullanılan veri toplama araçları ile bunların analizinde kullanılan tekniklerin detaylı bir biçimde açıklanması önemlidir (Creswell ve Miller, 2000). Sözü edilen gereklilikler kapsamında araştırmanın yöntem başlığı altında yukarıda sözü geçen bilgiler ayrıntılı biçimde açıklanmıştır. Nitel araştırmalarda objektiflik gerekliliği için teyit edilebilirlik gereğinin yerine getirilmesi gerekmektedir. Bu kapsamda makalenin ek bölümünde analiz bulgularının tümü paylaşılmıştır. Ekte yer alan tabloda her kazanımın hangi zihinsel beceri ile kodlandığını görmek mümkün olup, 
kazanımlar öğretim programlarındaki kodları ile yer almaktadır. Bu açıdan tabloda yer alan kazanımın ne olduğuna öğretim programlarından ulaşmak mümkündür. Nitel araştırmalarda güvenirlik gerekliliklerinden biri kodlayıcılar arası güvenirliktir. Bu gereklilik kapsamında analizler iki araştırmacı tarafından bağımsız olarak gerçekleştirilmiştir. Analiz sürecinde her bir araştırmacı kazanımı neden bu zihinsel beceri ile kodladığına ilişkin açıklamalar yazmıştır. Kodlayıcılar arası uyumun olmadığ kazanımlar analiz sürecinde alınan bu notlar temelinde birlikte değerlendirilmiştir. Kodlanan her bir kazanım üzerinde uzlaşmaya varıncaya kadar değerlendirmeler sürdürülmüştür.

\section{Bulgular}

\section{Araştırmanın Birinci Sorusuna İlişkin Bulgular}

Araştırmanın ilk sorusunda "Sosyal bilgiler alanı öğretim programlarında yer alan kazanımların geliştirmeyi amaçladığı zihinsel beceriler sınıflara göre nasıl bir dağılım göstermektedir?" sorusunun cevabı aranmıştır. Sosyal bilgiler alanı öğretim programlarında yer alan kazanımların geliştirmeyi amaçladığı zihinsel becerilerin sınıflara göre gösterdiği dağılım Tablo 2'de görüldüğü gibidir.

Tablo 2: Sosyal Bilgiler Alanı Öğretim Programlarına Ait Kazanımlarla Geliştirilmesi Amaçlanan Zihinsel Becerilerin Sınıflar Temelinde Dağılımı

\begin{tabular}{|c|c|c|c|c|c|c|c|c|c|c|}
\hline & $\begin{array}{c}1 . \\
\text { sinif }\end{array}$ & 2. & 3. & 4. & 5. & 6. & 7. & 8. & & lam \\
\hline & f & f & f & f & $\mathbf{f}$ & f & f & f & f & $\%$ \\
\hline Uygulama & 17 & 13 & 9 & 3 & 4 & 1 & 2 & 0 & 49 & 15.4 \\
\hline Hatırlama & 8 & 6 & 5 & 0 & 2 & 1 & 5 & 2 & 29 & 9.1 \\
\hline Analiz etme & 0 & 0 & 0 & 0 & 5 & 9 & 4 & 11 & 29 & 9.1 \\
\hline Karar verme & 11 & 6 & 3 & 5 & 1 & 1 & 1 & 0 & 28 & 8.8 \\
\hline Neden sonuç ilişkisi k. & 4 & 7 & 5 & 1 & 2 & 4 & 1 & 3 & 27 & 8.5 \\
\hline Örneklendirme & 0 & 2 & 7 & 2 & 5 & 1 & 3 & 1 & 21 & 6.6 \\
\hline Çıkarımda bulunma & 0 & 0 & 0 & 2 & 3 & 6 & 3 & 5 & 19 & 6 \\
\hline Áraştırma & 1 & 4 & 5 & 2 & 1 & 2 & 1 & 0 & 16 & 5 \\
\hline Dönüștürme & 2 & 2 & 4 & 2 & 1 & 3 & 0 & 0 & 14 & 4.4 \\
\hline Karşılaştırma & 0 & 1 & 1 & 6 & 1 & 1 & 1 & 0 & 11 & 3.5 \\
\hline İlişkilendirme & 0 & 1 & 1 & 1 & 1 & 1 & 1 & 4 & 10 & 3.1 \\
\hline Kanıt gösterme & 0 & 1 & 0 & 1 & 1 & 0 & 4 & 3 & 10 & 3.1 \\
\hline Gözlemleme & 4 & 2 & 0 & 3 & 0 & 0 & 0 & 0 & 9 & 2.8 \\
\hline Kavrama & 0 & 0 & 0 & 0 & 0 & 0 & 0 & 9 & 9 & 2.8 \\
\hline Ayırt etme & 6 & 0 & 0 & 1 & 0 & 0 & 0 & 0 & 7 & 2.2 \\
\hline Sorgulama & 0 & 0 & 0 & 0 & 3 & 2 & 2 & 0 & 7 & 2.2 \\
\hline $\begin{array}{l}\text { Türkçeyi doğru, güzel } \\
\text { ve etkili kullanma }\end{array}$ & 0 & 2 & 2 & 1 & 1 & 0 & 0 & 0 & 6 & 1.9 \\
\hline Değerlendirme & 0 & 0 & 0 & 0 & 1 & 1 & 2 & 1 & 5 & 1.6 \\
\hline Sinıflandırma & 0 & 3 & 1 & 1 & 0 & 0 & 0 & 0 & 5 & 1.6 \\
\hline Yenilikçi D. & 0 & 0 & 2 & 1 & 1 & 1 & 0 & 0 & 5 & 1.6 \\
\hline Siralama & 0 & 0 & 0 & 1 & 0 & 0 & 0 & 0 & 1 & 0.3 \\
\hline Problem çözme & 0 & 0 & 0 & 0 & 0 & 0 & 1 & 0 & 1 & 0.3 \\
\hline Toplam & 53 & 50 & 45 & 33 & 33 & 34 & 31 & 39 & 318 & 100 \\
\hline
\end{tabular}

Tablo 2. incelendiğinde sosyal bilgiler alanı öğretim programları ile toplam 22 zihinsel becerinin geliştirilmesinin amaçlandığı görülmektedir. Bu sayı, ilkokul 1.sınıfta 8, 2.sınıfta 13, 3.sinifta 12 , 4.sinifta 16, 5.sinifta16, 6.sinifta 14, 7.sinifta 14 ve 8.sinifta ise 9 zihinsel becerinin geliştirilmesi amaçladığ 1 görülmektedir. Programlarda 1., 2. ve 3. sınıfta en fazla geliştirilmesi amaçlanan zihinsel becerinin uygulama olduğu görülmektedir. 4. sınıfta karşılaştırma, 5. sınıfta örneklendirme ve analiz etme, 6 . sinıfta analiz etme, 7. sinıfta hatırlama ve 8 . sinıfta ise analiz etme 
zihinsel becerileri en yüksek orana sahiptir. Araştırmada, 1. 2.ve 3.sınıftaki kazanımlarda değerlendirme, sorgulama, problem çözme becerilerine yer verilmediği yenilikçi düşünmeye ise sadece 3. sınıfta iki kazanımda yer verildiği görülmektedir. 4.sınıfta sorgulama, analiz etme, değerlendirme ve problem çözme; 5.sınıfta sınıflandırma ve problem çözme; 6 sinıfta kanıt gösterme ve problem çözme; 7. sınıfta sınıflandırma ve yenilikçi düşünme; 8 . sınıfta uygulama, karar verme, sorgulama, yenilikçi düşünme ve problem çözme becerisini geliştirmeyi amaçlayan kazanım olmadığı görülmektedir. Sosyal bilgiler alanı öğretim programlarına ait kazanımların en fazla uygulama zihinsel becerisini geliştirmeyi amaçladığı görülmektedir. Bu zihinsel beceriyi hatırlama, analiz etme ve karar verme takip etmektedir. Öğretim programlarında en az sayıda geliştirilmesi amaçlanan zihinsel becerilerin sorgulama, değerlendirme, yenilikçi düşünme ve problem çözme becerisi olduğu görülmektedir. Kazanımların geliştirmeyi amaçladığ 1 hiçbir zihinsel becerinin sınıflara bağlı bir artış ya da azalış göstermediği dikkat çekmektedir. Araştırma, öğretim programlarında yer alan kazanımların yaklaşık yarısının ilk 4 sırada yer alan zihinsel becerileri geliştirmeyi amaçladığını göstermektedir.

\section{Araştırmanın İkinci Sorusuna İlişkin Bulgular}

Araştırmanın ikinci alt probleminde "Sosyal bilgiler alanı öğretim programlarında yer alan kazanımların geliştirmeyi amaçladığı zihinsel beceriler dersler, ünite/öğrenme alanlarına göre nasıl bir dağılım göstermektedir?" sorusunun cevabı aranmıştır. Sosyal bilgiler alanı öğretim programlarına ait kazanımların geliştirmeyi amaçladığı zihinsel becerilerin gösterdiği dağılım Tablo 3’te görüldüğü gibidir.

Tablo 3: Sosyal Bilgiler Alanı Öğretim Programlarına Ait Kazanımlarla Geliştirilmesi Amaçlanan Zihinsel Becerilerin Dersler Temelinde Dağılımı

\begin{tabular}{lcccccc}
\hline & Hayat Bilgisi & \multicolumn{2}{c}{ Sosyal Bilgiler } & \multicolumn{2}{c}{$\begin{array}{c}\text { T.C İnkılap Tarihi ve } \\
\text { Atatürkçülük }\end{array}$} \\
\cline { 2 - 7 } & f & \% & f & \% & f & \% \\
\hline Uygulama & 39 & 26.4 & 10 & 7.6 & 0 & 0 \\
Hatırlama & 19 & 12.8 & 8 & 6.1 & 2 & 5.1 \\
Analiz etme & 0 & 0 & 18 & 13.7 & 11 & 28.2 \\
Karar verme & 20 & 13.5 & 8 & 6.1 & 0 & 0 \\
Neden sonuç ilişkisi K. & 16 & 10.8 & 8 & 6.1 & 3 & 7.7 \\
Örneklendirme & 9 & 6.1 & 11 & 8.4 & 1 & 2.6 \\
Çıkarımda B. & 0 & 0 & 14 & 10.6 & 5 & 12.8 \\
Araştırma & 10 & 6.8 & 6 & 4.6 & 0 & 0 \\
Dönüştürme & 8 & 5.4 & 6 & 4.6 & 0 & 0 \\
Karșlaştırma & 2 & 1.4 & 9 & 6.9 & 0 & 0 \\
İlişkilendirme & 2 & 1.4 & 4 & 3.1 & 4 & 10.3 \\
Kanıt gösterme & 1 & 0.7 & 6 & 4.6 & 3 & 7.7 \\
Gözlemleme & 6 & 4.1 & 3 & 2.3 & 0 & 0 \\
Kavrama & 0 & 0 & 0 & 0 & 9 & 23.1 \\
Ayırt etme & 6 & 4.1 & 1 & 0.8 & 0 & 0 \\
Sorgulama & 0 & 0 & 7 & 5.3 & 0 & 0 \\
Türkçeyi doğru, güzel & 4 & 2.7 & 2 & 1.5 & 0 & 0 \\
ve etkili kullanma & & & & & & \\
Değerlendirme & 0 & 0 & 4 & 3.1 & 1 & 2.6 \\
Sinıflandırma & 4 & 2.7 & 1 & 0.8 & 0 & 0 \\
Yenilikçi D. & 2 & 1.4 & 3 & 2.3 & 0 & 0 \\
Siralama & 0 & 0 & 1 & 0.8 & 0 & 0 \\
Problem çözme & 0 & 0 & 1 & 0.8 & 0 & 0 \\
\hline Toplam & 148 & 100 & 131 & 100 & 39 & 100 \\
\hline
\end{tabular}


Tablo 3. incelendiğinde hayat bilgisi dersi ile 15; sosyal bilgiler dersi ile 21, T.C. İnk1lap Tarihi ve Atatürkçülük ders ile 9 zihinsel becerinin geliştirilmesinin amaçladığı görülmektedir. Hayat bilgisi dersinde en fazla geliştirilmesi amaçlanan zihinsel beceri uygulama iken sosyal bilgiler ve T.C. İnkılap Tarihi ve Atatürkçülük derslerinde ise analiz etme zihinsel becerisi en yüksek orana sahiptir. Hayat bilgisi dersi kazanımlarında analiz etme, çıkarımda bulunma, kavrama, sorgulama, değerlendirme ve problem çözme zihinsel becerisini geliştirmeyi amaçlayan kazanım olmadığı görülmektedir. Sosyal bilgiler dersinde kavrama zihinsel becerisini geliştirmeyi amaçlayan kazanım bulunmazken, T.C. İnkılap Tarihi ve Atatürkçülük dersinde ise uygulama, karar verme, araştırma, sorgulama, yenilikçi düşünme ve problem çözme zihinsel becerisini geliştirmeyi amaçlayan kazanım olmadığı görülmektedir.

Tablo 4. Hayat Bilgisi Dersi Öğretim Programlarına Ait Kazanımlarla Geliştirilmesi Amaçlanan Zihinsel Becerilerin Üniteler Temelinde Dağılımı

\begin{tabular}{|c|c|c|c|c|c|c|c|c|c|c|c|c|c|c|}
\hline & \multicolumn{2}{|c|}{$\begin{array}{c}\text { Okulumuz } \\
\text { da Hayat }\end{array}$} & \multicolumn{2}{|c|}{$\begin{array}{c}\text { Evimizde } \\
\text { Hayat }\end{array}$} & \multicolumn{2}{|c|}{$\begin{array}{c}\text { Sağlıklı } \\
\text { Hayat }\end{array}$} & \multicolumn{2}{|c|}{$\begin{array}{c}\text { Güvenli } \\
\text { Hayat }\end{array}$} & \multicolumn{2}{|c|}{$\begin{array}{c}\text { Ülkemiz } \\
\text { de Hayat }\end{array}$} & \multicolumn{2}{|c|}{$\begin{array}{c}\text { Doğada } \\
\text { Hayat }\end{array}$} & \multicolumn{2}{|c|}{ Toplam } \\
\hline & f & $\%$ & f & $\%$ & $\mathbf{f}$ & $\%$ & f & $\%$ & f & $\%$ & f & $\%$ & f & $\%$ \\
\hline Uygulama & 13 & 34.2 & 6 & 25 & 10 & 52.6 & 9 & 45 & 1 & 4.2 & 0 & 0 & 39 & 26.4 \\
\hline Karar verme & 7 & 18.4 & 2 & 8.3 & 3 & 15.8 & 0 & 0 & 4 & 16.7 & 4 & 17.4 & 20 & 13.5 \\
\hline Hatırlama & 3 & 7.9 & 3 & 12.5 & 1 & 5.3 & 5 & 25 & 5 & 20.8 & 2 & 8.7 & 19 & 12.8 \\
\hline Neden sonuç & 5 & 13.2 & 3 & 12.5 & 3 & 15.8 & 0 & 0 & 3 & 12.5 & 2 & 8.7 & 16 & 10.8 \\
\hline ilişkisi k. & & & & & & & & & & & & & & \\
\hline Araştırma & 1 & 2.6 & 1 & 4.2 & 0 & 0 & 0 & 0 & 5 & 20.8 & 3 & 13 & 10 & 6.8 \\
\hline Örneklendirme & 0 & 0 & 3 & 12.5 & 0 & 0 & 2 & 10 & 0 & 0 & 4 & 17.4 & 9 & 6.1 \\
\hline Dönüştürme & 2 & 5.3 & 2 & 8.3 & 0 & 0 & 1 & 5 & 1 & 4.2 & 2 & 8.7 & 8 & 5.4 \\
\hline Ayırt etme & 1 & 2.6 & 1 & 4.2 & 0 & 0 & 1 & 5 & 2 & 8.3 & 1 & 4.3 & 6 & 4.1 \\
\hline Gözlemleme & 0 & 0 & 0 & 0 & 0 & 0 & 1 & 5 & 1 & 4.2 & 4 & 17.4 & 6 & 4.1 \\
\hline Sinıflandırma & 2 & 5.3 & 1 & 4.2 & 0 & 0 & 1 & 5 & 0 & 0 & 0 & 0 & 4 & 2.7 \\
\hline $\begin{array}{l}\text { Türkçeyi doğru, } \\
\text { güzel ve etkili } \\
\text { kullanma }\end{array}$ & 3 & 7.9 & 0 & 0 & 0 & 0 & 0 & 0 & 1 & 4.2 & 0 & 0 & 4 & 2.7 \\
\hline İlişkilendirme & 0 & 0 & 0 & 0 & 1 & 5.3 & 0 & 0 & 1 & 4.2 & 0 & 0 & 2 & 1.4 \\
\hline Karşılaştırma & 0 & 0 & 1 & 4.2 & 0 & 0 & 0 & 0 & 0 & 0 & 1 & 4.3 & 2 & 1.4 \\
\hline Yenilikçi D. & 1 & 2.6 & 1 & 4.2 & 0 & 0 & 0 & 0 & 0 & 0 & 0 & 0 & 2 & 1.4 \\
\hline Kanit göster & 0 & 0 & 0 & 0 & 1 & 5.3 & 0 & 0 & 0 & 0 & 0 & 0 & 1 & 0.7 \\
\hline Toplam & 38 & 100 & 24 & 100 & 19 & 100 & 20 & 100 & 24 & 100 & 23 & 100 & 148 & 100 \\
\hline
\end{tabular}

Tablo 4. incelendiğinde okulumuzda hayat ünitesinde en fazla geliştirilmesi amaçlanan zihinsel becerinin uygulama olduğu görülmektedir. Bu ünitede gözlemleme, karşılaştırma ve kanıt gösterme zihinsel becerisini geliştiren bir kazanım olmadığı görülmektedir. Evimizde hayat ünitesinde en fazla geliştirilmesi amaçlanan zihinsel beceri uygulamadır. Bu ünitede gözlemleme, ilişkilendirme ve kanıt gösterme zihinsel becerisini geliştiren bir kazanım yoktur. Sağlıklı hayat ünitesinde en fazla geliştirilmesi amaçlanan zihinsel beceri uygulama iken araştırma, dönüştürme ve yenilikçi düşünme zihinsel becerisini geliştirmeyi amaçlayan bir kazanım olmadığı görülmektedir. Güvenli hayat ünitesinde en fazla geliştirilmesi amaçlanan zihinsel beceri uygulamadır. Bu temada karar verme, neden sonuç ilişsisi kurma ve yenilikçi düşünme zihinsel becerisini geliştiren bir kazanım bulunmamaktadır. Ülkemizde hayat ünitesinde en fazla geliştirilmesi amaçlanan zihinsel beceri hatırlama iken kanıt gösterme ve yenilikçi düşünme zihinsel becerisini geliştiren bir kazanım olmadığı görülmektedir. Doğada hayat ünitesinde en fazla geliştirilmesi amaçlanan zihinsel beceri karar verme, örneklendirme ve gözlemlemedir. Bu ünitede kanıt gösterme ve yenilikçi düşünme zihinsel becerisini geliştiren bir kazanım olmadığı görülmektedir. 
Tablo 5. Sosyal Bilgiler Dersi Öğretim Programlarına Ait Kazanımlarla Geliştirilmesi Amaçlanan Zihinsel Becerilerin Öğrenme Alanları Temelinde Dă̆ılımı

\begin{tabular}{|c|c|c|c|c|c|c|c|c|c|c|c|c|c|c|c|c|}
\hline & \multicolumn{2}{|c|}{$\begin{array}{l}\text { Birey ve } \\
\text { Toplum }\end{array}$} & \multicolumn{2}{|c|}{$\begin{array}{c}\text { Kültürr } \\
\text { ve Miras }\end{array}$} & \multicolumn{2}{|c|}{$\begin{array}{l}\text { İnsanlar, } \\
\text { Yerler } \\
\text { ve } \\
\text { Çevreler }\end{array}$} & \multicolumn{2}{|c|}{$\begin{array}{c}\text { Bilim, } \\
\text { Teknoloji } \\
\text { ve } \\
\text { Toplum }\end{array}$} & \multicolumn{2}{|c|}{$\begin{array}{l}\text { Üretim, } \\
\text { Dağıtım } \\
\text { ve } \\
\text { Tüketim }\end{array}$} & \multicolumn{2}{|c|}{$\begin{array}{c}\text { Etkin } \\
\text { Vatanda } \\
\text { şlık }\end{array}$} & \multicolumn{2}{|c|}{$\begin{array}{l}\text { Küresel } \\
\text { Bağlantı } \\
\quad \text { lar }\end{array}$} & \multicolumn{2}{|c|}{ Toplam } \\
\hline & $\mathbf{f}$ & $\%$ & f & $\%$ & f & $\%$ & f & $\%$ & $\mathrm{f}$ & $\%$ & f & $\%$ & f & $\%$ & f & $\%$ \\
\hline Analiz & 2 & 11.1 & 3 & 15.8 & 0 & 0 & 1 & 5.6 & 6 & 26.1 & 3 & 16.6 & 3 & 18.8 & 18 & 13.7 \\
\hline Çıkarımda B. & 1 & 5.6 & 4 & 21.1 & 5 & 26.3 & 2 & 11.1 & 1 & 4.3 & 2 & 11.1 & 0 & 0 & 15 & 11.5 \\
\hline Örneklendirme & 1 & 5.6 & 2 & 10.5 & 4 & 21.1 & 1 & 5.6 & 2 & 8.8 & 1 & 5.6 & 1 & 6.3 & 12 & 9.2 \\
\hline Uygulama & 3 & 16.6 & 0 & 0 & 1 & 5.3 & 4 & 22.2 & 2 & 8.8 & 0 & 0 & 0 & 0 & 10 & 7.6 \\
\hline $\begin{array}{l}\text { Neden sonuç } \\
\text { ilişsisi K. }\end{array}$ & 1 & 5.6 & 4 & 21.1 & 0 & 0 & 1 & 5.6 & 1 & 4.3 & 0 & 0 & 1 & 6.3 & 8 & 6.1 \\
\hline Karşılaştırma & 2 & 11.1 & 2 & 10.5 & 0 & 0 & 1 & 5.6 & 0 & 0 & 1 & 5.6 & 2 & 12.5 & 8 & 6.1 \\
\hline Karar verme & 1 & 5.6 & 0 & 0 & 0 & 0 & 0 & 0 & 4 & 17.4 & 2 & 11.1 & 1 & 6.3 & 8 & 6.1 \\
\hline Hatırlama & 0 & 0 & 1 & 5.3 & 0 & 0 & 0 & 0 & 1 & 4.3 & 3 & 16.6 & 2 & 12.5 & 7 & 5.3 \\
\hline Sorgulama & 2 & 11.1 & 0 & 0 & 1 & 5.3 & 2 & 11.1 & 0 & 0 & 0 & 0 & 2 & 12.5 & 7 & 5.3 \\
\hline Araştırma & 1 & 5.6 & 1 & 5.3 & 0 & 0 & 2 & 11.1 & 1 & 4.3 & 0 & 0 & 1 & 6.3 & 6 & 4.6 \\
\hline Dönüştürme & 0 & 0 & 0 & 0 & 6 & 31.6 & 0 & 0 & 0 & 0 & 0 & 0 & 0 & 0 & 6 & 4.6 \\
\hline Kanıt gösterme & 1 & 5.6 & 0 & 0 & 1 & 5.3 & 1 & 5.6 & 0 & 0 & 2 & 11.1 & 1 & 6.3 & 6 & 4.6 \\
\hline Değerlendirme & 1 & 5.6 & 1 & 5.3 & 0 & 0 & 1 & 5.6 & 1 & 4.3 & 1 & 5.6 & 0 & 0 & 5 & 3.8 \\
\hline İlişkilendirme & 0 & 0 & 0 & 0 & 0 & 0 & 0 & 0 & 1 & 4.3 & 3 & 16.6 & 0 & 0 & 4 & 3.1 \\
\hline Yenilikçi D. & 0 & 0 & 0 & 0 & 0 & 0 & 1 & 5.6 & 2 & 8.8 & 0 & 0 & 0 & 0 & 3 & 2.3 \\
\hline $\begin{array}{l}\text { Türkçeyi } \\
\text { doğru, güzel ve } \\
\text { etkili kullanma }\end{array}$ & 0 & 0 & 1 & 5.3 & 0 & 0 & 0 & 0 & 0 & 0 & 0 & 0 & 1 & 6.3 & 2 & 1.5 \\
\hline Gözlemleme & 1 & 5.6 & 0 & 0 & 0 & 0 & 0 & 0 & 1 & 4.3 & 0 & 0 & 0 & 0 & 2 & 1.5 \\
\hline Siralama & 1 & 5.6 & 0 & 0 & 0 & 0 & 0 & 0 & 0 & 0 & 0 & 0 & 0 & 0 & 1 & 0.8 \\
\hline Ayurt etme & 0 & 0 & 0 & 0 & 1 & 5.3 & 0 & 0 & 0 & 0 & 0 & 0 & 0 & 0 & 1 & 0.8 \\
\hline Sinıflama & 0 & 0 & 0 & 0 & 0 & 0 & 1 & 5.6 & 0 & 0 & 0 & 0 & 0 & 0 & 1 & 0.8 \\
\hline Problem Ç. & 0 & 0 & 0 & 0 & 0 & 0 & 0 & 0 & 0 & 0 & 0 & 0 & 1 & 6.3 & 1 & 0.8 \\
\hline Toplam & 18 & 100 & 19 & 100 & 19 & 100 & 18 & 100 & 23 & 100 & 18 & 100 & 16 & 100 & 131 & 100 \\
\hline
\end{tabular}

Tablo 5. incelendiğinde birey ve toplum öğrenme alanında en fazla geliştirilmesi amaçlanan zihinsel becerinin uygulama olduğu görülmektedir. Bu öğrenme alanında hatırlama, dönüştürme, yenilikçi düşünme ve problem çözme zihinsel becerisini geliştirmeyi amaçlayan kazanım bulunmamaktadır. Kültür ve miras öğrenme alanında en fazla geliştirilmesi amaçlanan zihinsel beceri çıkarımda bulunma ve neden sonuç ilişkisi kurma iken uygulama, karar verme, sorgulama, kanıt gösterme, yenilikçi düşünme, kanıt gösterme ve problem çözme zihinsel becerisini geliştirmeyi amaçlayan zihinsel beceri olmadığı görülmektedir. İnsanlar, yerler ve çevreler öğrenme alanında en fazla geliştirilmesi amaçlanan zihinsel beceri dönüştürmedir. Bu öğrenme alanında analiz etme, neden sonuç ilişkisi kurma, karar verme, hatırlama, araştırma, değerlendirme, yenilikçi düşünme ve problem çözme zihinsel becerisini geliştirmeyi amaçlayan kazanım bulunmamaktadır. Bilim, teknoloji ve toplum öğrenme alanında en fazla geliştirilmesi amaçlanan zihinsel beceri uygulama iken karar verme, hatırlama, dönüştürme, ilişkilendirme ve problem çözme zihinsel becerisini geliştirmeyi amaçlayan kazanım olmadığı görülmektedir. Üretim dağıtım ve tüketim öğrenme alanında en fazla geliştirilmesi amaçlanan zihinsel beceri analiz etmedir. Bu öğrenme alanında sorgulama, dönüştürme ve problem çözme zihinsel becerisini geliştirmeyi amaçlayan bir kazanım olmadığı görülmektedir. Etkin vatandaş öğrenme alanında analiz etme, hatırlama ve ilişkilendirme zihinsel becerilerini geliştirmeyi amaçlayan kazanımlar eş sayıda yer alırken sorgulama, araştırma, dönüştürme, yenilikçi düşünme ve problem çözme becerisini geliştirmeyi amaçlayan kazanım bulunmamaktadır. Küresel bağlantılar temasında en fazla geliştirilmesi amaçlanan zihinsel beceri 
analiz etmedir. $\mathrm{Bu}$ öğrenme alanında çıkarımda bulunma, uygulama, değerlendirme ve yenilikçi düşünme becerisini geliştirmeyi amaçlayan kazanım bulunmamaktadır.

Tablo 6. TC İnkılap Tarihi Ve Atatürkçülük Dersi Öğretim Programlarına Ait

Kazanımlarla Geliștirilmesi Amaçlanan Zihinsel Becerilerin Temalar Temelinde Dağılımı

\begin{tabular}{|c|c|c|c|c|c|c|c|c|c|c|c|c|c|c|c|}
\hline & \multicolumn{2}{|c|}{$\begin{array}{l}\text { Bir } \\
\text { Kahraman } \\
\text { Doğuyor }\end{array}$} & $\begin{array}{l}\text { Millî } \\
\text { Uyanış: } \\
\text { Bağımsızl } \\
\text { lk } \\
\text { Yolunda } \\
\text { Atılan } \\
\text { Adımlar }\end{array}$ & \multicolumn{2}{|c|}{$\begin{array}{l}\text { Millî } \\
\text { Bir } \\
\text { Destan: } \\
\text { Ya } \\
\text { İstiklal } \\
\text { Ya } \\
\text { Ölüm! }\end{array}$} & \multicolumn{2}{|c|}{$\begin{array}{l}\text { Atatürk } \\
\text { çülük } \\
\text { ve } \\
\text { Çağdaşl } \\
\text { aşan } \\
\text { Türkiye }\end{array}$} & \multicolumn{2}{|c|}{$\begin{array}{l}\text { Demokra } \\
\text { tikleşme } \\
\text { Çabaları }\end{array}$} & \multicolumn{2}{|c|}{$\begin{array}{l}\text { Atatürk } \\
\text { Dönemi } \\
\text { Türk Dış } \\
\text { Politikası }\end{array}$} & \multicolumn{2}{|c|}{$\begin{array}{l}\text { Atatürk' } \\
\text { ün } \\
\text { Ölümü ve } \\
\text { Sonrası }\end{array}$} & \multicolumn{2}{|c|}{ Toplam } \\
\hline & f & $\%$ & f $\%$ & f & $\%$ & $\mathbf{f}$ & $\%$ & f & $\%$ & f & $\%$ & f & $\%$ & f & $\%$ \\
\hline Analiz & 0 & 0 & 337.5 & 2 & 28.6 & 1 & 11.1 & 2 & 66.7 & 1 & 33.3 & 2 & 40 & 11 & 28.2 \\
\hline Kavrama & 1 & 25 & $1 \quad 12.5$ & 2 & 28.6 & 5 & 55.6 & 0 & 0 & 0 & 0 & 0 & 0 & 9 & 23.1 \\
\hline Çıkarımda B. & 1 & 25 & 112.5 & 2 & 28.6 & 0 & 0 & 0 & 0 & 0 & 0 & 1 & 20 & 5 & 12.7 \\
\hline İlişkilendirme & 1 & 25 & 112.5 & 0 & 0 & 1 & 11.1 & 0 & 0 & 0 & 0 & 1 & 20 & 4 & 10.3 \\
\hline Kanıt gösterme & 0 & 0 & $0 \quad 0$ & 1 & 14.2 & 0 & 0 & 1 & 33.3 & 1 & 33.3 & 0 & 0 & 3 & 7.7 \\
\hline Hatırlama & 0 & 0 & $0 \quad 0$ & 0 & 0 & 1 & 11.1 & 0 & 0 & 1 & 33.3 & 0 & 0 & 2 & 5.1 \\
\hline $\begin{array}{l}\text { Neden sonuç } \\
\text { ilișkisi K. }\end{array}$ & 1 & 25 & 112.5 & 0 & 0 & 1 & 11.1 & 0 & 0 & 0 & 0 & 0 & 0 & 3 & 7.7 \\
\hline Değerlendirme & 0 & 0 & 112.5 & 0 & 0 & 0 & 0 & 0 & 0 & 0 & 0 & 0 & 0 & 1 & 2.6 \\
\hline Örneklendirme & 0 & 0 & $0 \quad 0$ & 0 & 0 & 0 & 0 & 0 & 0 & 0 & 0 & 1 & 20 & 1 & 2.6 \\
\hline Toplam & 4 & 100 & $8 \quad 100$ & 7 & 100 & 9 & 100 & 3 & 100 & 3 & 100 & 5 & 100 & 39 & 100 \\
\hline
\end{tabular}

Tablo 6. incelendiğinde Bir Kahraman Uyanıyor ünitesinde kavrama, çıkarımda bulunma, ilişkilendirme ve neden sonuç ilişkisi kurma zihinsel becerisini geliştirmeyi amaçlayan eş sayıda kazanım olduğu görülmektedir. Millî Uyanış: Bağımsızlık Yolunda Atılan Adımlar ünitesinde en fazla geliştirilmesi amaçlanan zihinsel beceri analiz etme iken kanıt gösterme, hatırlama ve örneklendirme zihinsel becerisini geliştirmeyi amaçlayan kazanım olmadığı görülmektedir. Millî Bir Destan: Ya İstiklal Ya Ölüm! ünitesinde en yüksek orana sahip olan zihinsel beceriler analiz etme, kavrama ve çıkarımda bulunmadır. Bu ünitede hatırlama, neden sonuç ilişkisi kurma ve değerlendirme zihinsel becerisini geliştirmeyi amaçlayan kazanım bulunmamaktadır. Atatürkçülük ve Çağdaşlaşan Türkiye ünitesinde en fazla geliştirilmesi amaçlanan zihinsel beceri kavramadır. Bu ünitede çıkarımda bulunma, kanıt gösterme ve değerlendirme zihinsel becerisini geliştirmeyi amaçlayan kazanım olmadığı görülmektedir. Demokratikleşme Çabaları ünitesinde en fazla geliştirilmesi amaçlanan zihinsel beceri analiz etme iken çıarımda bulunma, neden sonuç ilişkisi kurma ve değerlendirme zihinsel becerilerini geliştirmeyi amaçlayan kazanım olmadığ görülmektedir. Atatürk Dönemi Türk Dış Politikası ünitesinde analiz etme, kanıt gösterme ve hatırlama zihinsel becerisini geliştirmeyi amaçlayan kazanımların sayıları eşittir. $\mathrm{Bu}$ ünitede çıkarımda bulunma, değerlendirme ve örneklendirme zihinsel becerilerini geliştirmeyi amaçlayan kazanım bulunmamaktadır. Atatürk'ün Ölümü ve Sonrası ünitesinde en fazla geliştirilmesi amaçlanan zihinsel beceri analiz etme iken kanıt gösterme, hatırlama, neden sonuç ilişkisi kurma ve değerlendirme zihinsel becerisini geliştirmeyi amaçlayan kazanım olmadığı görülmektedir.

\section{Tartışma, Sonuç ve Öneriler}

$\mathrm{Bu}$ araştırmada sosyal bilgiler alanı öğretim programlarında yer alan kazanımların geliştirmeyi amaçladığı zihinsel becerilerin dağılımını incelemek amaçlanmıştır. 21.yüzyılda öğrencilerin zihinsel becerilerinde gelişim sağlamak, okulların önemli bir amacı haline gelmiştir. $\mathrm{Bu}$ kapsamda özellikle 1980 sonrası çeşitli program yaklaşımlarının ortaya çıktığı görülmektedir. Bunlardan en kabul göreni, zihinsel becerileri öğretim programının içsel bir parçası olarak geliştirilmesine izin veren yaklaşımdır. Türkiye'de özellikle 2005 yılından sonra geliştirilen programlarda bu yaklaşımın özelliklerini görmek mümkündür. Öğretim programları kapsamına 
alınan zihinsel becerileri geliştirmenin en temel gerekliliklerden biri, programlarda bu zihinsel becerilerin gelişimini amaçlayan kazanımların yer almasıdır. Kazanımlarda kendine yer bulamayan bir zihinsel beceri, öğretme ve öğrenme sürecinde ve dolayısıyla öğrenme çıktılarında kendine yer bulamayacaktır. 2018 yılında güncellenen sosyal bilgiler alanı öğretim programlarında zihinsel becerilerin öneminin altının çizildiği ve program geliştirme çalışmalarında beceriler ile kazanımlar arasındaki ilişkinin dikkate alındığı ifade edilmektedir. Ancak bu iddianın kazanımlara hangi oranda yansitıldığ bilgiler ve T.C. İnkılap Tarihi ve Atatürkçülük dersi öğretim programı kazanımlarının tamamı, geliştirmeyi amaçladığ 1 zihinsel beceriler temelinde analiz edilmiştir. Araştırmada sosyal bilgiler alanı öğretim programları ile toplam 22 farklı zihinsel becerinin geliştirilmesinin amaçlandığı görülmüştür. Programda en fazla geliştirilmesi amaçlanan zihinsel beceri uygulama iken en az sayıda geliştirilmesi amaçlanan zihinsel beceri problem çözmedir.

Araştırma sorgulama, problem çözme, değerlendirme ve yenilikçi düşünme zihinsel becerilerini geliştirmeyi amaçlayan kazanımların düşük oranlara sahip olduğunu göstermiştir. $\mathrm{Bu}$ durum üst düzey zihinsel becerileri geliştirme konusunda sosyal bilgiler alanı öğretim programlarının yeterliliği konusunda oldukça düşündürücüdür. Nitekim öğretim programının amaç ve gerekçelerinde üst düzey düşünme becerilerinin öneminin altı çizilmekte, programlarda yer alan yeterlik çerçevesi ve alana özgü beceriler kapsamında bu üst düzey zihinsel becerilerin isimleri geçmektedir (MEB, 2018; MEB, 2017). Buna karşın söz konusu becerilerin kazanımlara tam olarak yansıtılmadığı görülmektedir. Alanyazında benzer sonuçlara işaret eden araştırmaları görmek mümkündür. Örneğin Hayat bilgisi dersi öğretim programının öğretmenler tarafından değerlendirildiği araştırmaya göre yaratıcı düşünme öğrencilerin en az kazanmış olduğu düşünülen beceri olduğu belirlenmiştir (Öztürk, 2015). Başka bir araştırmada, sınıf öğretmeni adaylarının eleştirel düşünmeye 4-5. sınıf sosyal bilgiler etkinliklerinin orta düzeyde uygun olarak gördükleri ifade edilmektedir (Demir, Tutkun, Şahin ve Genç, 2014). Bu araştırmada ise sorgulama zihinsel becerisinin sosyal bilgiler alanı öğretim programlarındaki oranının \%2.2; yenilikçi düşünmenin oranının ise \%1.7 olduğu görülmektedir. Bununla birlikte T.C. İnkılap Tarihi ve Atatürkçülük dersi kazanımlarında sorgulama ve yenilikçi düşünme zihinsel becerisini geliştirmeyi amaçlayan kazanıma rastlanmamıştır. Hayat bilgisi dersi öğretim programında ise sorgulama zihinsel becerisini geliştirmeyi amaçlayan kazanım bulunmadığı ve yenilikçi düşünme becerisini geliştiren kazanımların oranının ise \%1.4 olduğu görülmektedir.

Kazanımların geliştirmeyi amaçladığı zihinsel becerilerin düzeyler temelinde dağılımına ilişkin bulgular incelendiğinde üst düzey zihinsel becerilerin oranının $\% 50.2$ olduğu görülmektedir. Benzer araştırmalar bu bulguyu doğrular niteliktedir. Örneğin sosyal bilgiler dersi öğretim programına ait kazanımların bilişsel düzeylerinin incelendiği bir araştırmada, 7. sınıf sosyal bilgiler dersi öğretim programında bilişsel alanı yansıttığına karar verilen 37 kazanımın 17 tanesi alt düzey, 20 tanesi üst düzey öğrenme hedeflerini içerdiği bulgusuna ulaşılmıştır (Aydemir ve Adamaz, 2017). Başka bir bulgu ise 6 . sınıf sosyal bilgiler dersi öğretim programında incelenen 43 kazanımın 22 'sinin üst düzey düşünme becerilerini geliştirmeyi amaçladığını göstermektedir (Taşkıran, 2014). Benzer bir bulgu Gazel ve Erol (2012) tarafından gerçekleştirilen araştırmada da görülmektedir. Adı geçen araştırma bilişsel alanda yer aldığı belirlenen 30 kazanım içinden 14 tanesinin alt düzey, 16 tanesinin üst düzey olduğu görülmektedir. T.C. İnkılap Tarihi ve Atatürkçülük dersi özelinde yapılan başka bir araştırmanın bulguları incelendiğinde, üst düzey bilişsel becerilerin \%66.6'lık bir orana sahip olduğu görülmektedir (Gezer, Şahin, Öner-Sünkür ve Meral, 2014).

Araştırma, öğretim programlarına ait kazanımların yaklaşık yarısının ilk dört sırada yer alan uygulama, hatırlama, analiz etme ve karar verme zihinsel becerilerini geliştirmeyi amaçladığını göstermektedir. Bu sonuca dayalı olarak programda ifade edilen zihinsel becerilerdeki çeşitliliğin kazanımlara yansımadığ 1 yorumunda bulunmak mümkündür. Benzer bir bulguyu sosyal bilgiler dersi öğretim programına yönelik yakın dönem araştırmalarında da görmek mümkündür. Araştırmada, 
2005 yılından bu yana program geliştirme çalışmalarının yapıldığı ancak güncel öğretim programın içerik boyutunda köklü değişikliklerin gerçekleştirilmemiş olduğu ifade edilmektedir (Çoban ve Akşit, 2018). 2005 programında 15 temel beceriye yer verilmesine karşın 2018 programında sosyal bilgiler dersinde bu sayının 27'ye yükseldiği görülmektedir. 2018 programında da yer verilen alana özgü beceriler arasında yer alan eleştirel okuma, yenilikçilik ve problem çözme zihinsel becerilerine karşılık gelen sorgulama, yenilikçi düşünme ve problem çözme zihinsel becerilerini geliştirmeyi amaçlayan kazanımların oranının programda oldukça düşük olduğu görülmektedir. Taş ve Kıroğlu (2018)'nun da ifade ettiği gibi önemli olan içeriği ve kazanımları artırmak değil onların zihinsel becerilerle ilişkilerini kurmak olmalıdır.

Araştırma bulgularının işaret ettiği bir diğer sonuç kazanımların geliştirmeyi amaçladığı zihinsel becerilerin, kendi aralarında ve kademeler temelinde orantılı bir dağ 1 lıma sahip olmamasıdır. Örneğin uygulama zihinsel becerisini geliştirmeyi amaçlayan 49 kazanım varken problem çözme zihinsel becerisini geliştirmeyi amaçlayan sadece bir kazanım olduğu görülmektedir. Benzer bir sonucun görüldüğ̈̈ bir araştırmada, sosyal bilgiler çalışma kitaplarında ortak ve derse özgü becerilerin tüm sınıflar düzeyinde dengeli bir dağılım içerisinde olmadığı ve becerilerin alt sınıflardan üst sınıflara doğru dengeli ve yükselen bir grafik çizmediği bulunmuştur (Aydemir ve Adamaz, 2017). Programda yer alan beceriler birbirini destekler niteliktedir ve bir beceri diğerinden daha önemli değildir. Bu nedenle becerilerin dengeli dağılımı sağlanmalıdır (Aydemir ve Adamaz, 2017; Semerci ve Yanpar-Yelken, 2010; Taşkıran, 2014). Zihinsel becerilerin öğretim programlarındaki bu orantısız dağılımı, program geliştirme sürecinde zihinsel becerilerin gelişiminin hangi oranda dikkate alındığını düşündürmektedir.

T.C. İnkılap tarihi ve Atatürkçülük dersine yönelik bulgular incelendiğinde, zihinsel becerilerin çeşitliliği açısından keskin bir daralmanın yaşandığı dikkat çekmektedir. T.C. İnkılap Tarihi ve Atatürkçülük dersiyle geliştirilmesi amaçlanan zihinsel beceri sayısı sosyal bilgiler dersine kıyasla 1/3 oranında düşmektedir. Ayrıca T.C. İnkılap tarihi ve Atatürkçülük dersinin neredeyse tamamının çıkarımda bulunma, analiz etme ve kavrama zihinsel becerilerinden oluştuğu görülmektedir. Benzer bir bulguyu Gezer, vd.'nin (2014) araştırmasında görmek mümkündür. Araştırmasında T.C. İnkılap tarihi ve Atatürkçülük dersi öğretim programında hatırlama, uygulama ve oluşturmaya ait kazanımın olmadığını ifade etmektedir.

Sosyal bilgiler alanı öğretim program kazanımlarının, 22 farklı zihinsel beceriyi geliştirmeyi amaçlaması programlara yönelik olumlu bir yön olarak karşımıza çıkmaktadır. Ancak diğer yandan zihinsel becerilerin kendi içinde ve kademeler temelinde orantılı bir dağılım göstermiyor olması, bir takım zihinsel becerilere ağırlık verilirken bir takım zihinsel becerilere düşük oranda yer verilmesi programda geliştirilmesi gereken noktalara işaret etmektedir. Okulların geleceğin dünyasının gerekliliklerini yerine getirebilmesi için program geliştirme sürecinde, konu alanının zihinsel becerileri geliştirme konusunda sahip olduğu potansiyelden en üst düzeyde yararlanılmas1 gerekmektedir. $\mathrm{Bu}$ açıdan araştırma bulgularına dayalı olarak zihinsel becerileri geliştirme konusunda sosyal bilgiler alanının olanaklarından hangi oranda doğru bir şekilde yararlanıldığ 1 üzerinde durulması büyük önem taşımaktadır. Bu kapsamda, program geliştirme sürecinde "Sosyal bilgiler alanının zihinsel becerileri geliştirme konusunda sahip olduğu potansiyelden en üst düzeyde yararlanmak için program geliştirme sürecinde ne gibi çalışmalar yürütülebilir? Zihinsel beceriler sınıf düzeyleri temelinde nasıl bir sarmal yapı içinde ele alınabilir? Zihinsel becerilerin ön koşul/tamamlayıcı öğrenmeleri nelerdir?” sorularına odaklanmanın önemli olduğu düşünülmektedir. Araştırma bulgularına dayalı olarak bir diğer önemli nokta ise program kapsamına alınan zihinsel becerilere ilişkin açıklamaların daha detaylandırılması gerekliliğidir. Örneğin öğretim programlarında yer alan zihinsel becerilerin kapsamının ne olduğu ve bu becerinin hangi kazanım/kazanımlar çerçevesinde geliştirilmesi amaçlandığına ilişkin bilgilere yer verilmesi gerektiği düşünülmektedir. 
$\mathrm{Bu}$ araştırmanın sınırlılığını 1-8 sınıf kapsamına giren sosyal bilgiler alanı öğretim programlarının sadece kazanım bileşeninin incelenmiş olması oluşturmaktadır. Gelecek araştırmalar öğretim programlarının zihinsel becerileri geliştirme konusunda var olan durumunu betimlemek için programın diğer öğelerini inceleme kapsamına alabilirler. Bunun yanında örneklem grubuna uygulanmakta olan programın dâhil edildiği araştırmaların yapılması alanyazında önemli bir eksikliği dolduracaktır.

\section{Kaynakça}

Anagün, Ş. S., Atalay, N., Kılıç, Z. \& Yaşar, S. (2016). Öğretmen adaylarına yönelik 21. Yüzyıl becerileri yeterlilik algıları ölçeğinin geliştirilmesi: Geçerlik ve güvenirlik çalışması. Pamukkale Üniversitesi Eğitim Fakültesi Dergisi, 40(40), 160-175. https://doi.org/10.9779/puje768.

Anderson, L. W. \& Krathwohl, D. R. (2001). A Taxonomy for learning, teaching and assessing. A revision of Bloom's Taxonomy of educational objectives. Longman: New York.

Aydemir, M. \& Adamaz, K. (2017). Sosyal bilgiler öğrenci çalışma kitaplarının sosyal bilgiler dersi öğretim programındaki beceriler açısından incelenmesi. Uluslararası Alan Eğitimi Dergisi, 3(1), 106-119. https://doi.org/10.32570/ijofe.342445.

Beyer, B. (1984). Improving thinking skills: Practical approaches. The Phi Delta Kappan, 65(8), 556-560.

Bloom, B. S. (Ed.) (1956). Taxonomy of Educational objectives. The Classification of Educational Goals. Handbook I: Cognitive Domain. New York: Longmans, Gren and Company Inc. https://doi.org/10.32570/ijofe.342445.

Bozkurt, Ş. B. \& Çakır, H. (2016). Ortaokul öğrencilerinin 21. yüzyıl öğrenme beceri düzeylerinin cinsiyet ve sınıf seviyesine göre incelenmesi. Pamukkale Üniversitesi Eğitim Fakültesi Dergisi, 39(39), 69-82. https://doi.org/10.9779/puje757.

Çoban, O. \& Akşit, İ. (2018). 2005 ve 2017 Sosyal bilgiler öğretim programlarının öğrenme alanı, kazanım, kavram, değer ve beceri boyutları açısından karşılaştırılması. Journal of History Culture and Art Research, 7(1), 479-505. https://doi.org/10.7596/taksad.v7i1.1395.

Creswell, J.W. \& Miller, D.L. (2000) Determining Validity in Qualitative Inquiry. Theory into Practice, 39, 124-130. https://doi.org/10.1207/s15430421tip3903_2.

Demir, M. K., Tutkun, T., Şahin, Ç. \& Genç, S. Z. (2014). Sosyal bilgiler ders kitaplarındaki soruların eleştirel düşünmeye uygunluğu. Abant İzzet Baysal Üniversitesi Eğitim Fakültesi Dergisi. 14(1), 290-303. https://doi.org/10.17240/aibuefd.2014.14.1-5000091513.

Diveck, C. S. \& Molden, D. C. (2005). Self-Theories: Their impact on competence motivation and acquisition. In A. J. Elliot \& C. S. Dweck (Eds.), Handbook of competence and motivation (p. 122-140). Guilford Publications.

Gagné, R. M. \& Briggs, L.J. (1979). Principles of instructional design. New York: Holt, Rinehart \& Winston.

Gazel, A. A. \& Erol, H. (2012). İlköğretim 7. sınıf sosyal bilgiler ders programındaki kazanımların taksonomik açıdan değerlendirilmesi. Kuramsal Eğitimbilim Dergisi, 5(2), 202-222.

Gezer, M., Şahin, İ., Sünkür, M. Ö. \& Meral, E. (2014). 8. Sınıf Türkiye Cumhuriyeti İnkılâp Tarihi ve Atatürkçülük dersi kazanımlarının revize edilmiş Bloom taksonomisine göre değerlendirilmesi. Bartın Üniversitesi Eğitim Fakültesi Dergisi, 3(1), 433-455. https://doi.org/10.14686/buefad.201416226 
Göksün, D. O. \& Kurt, A. A. (2017). The relationship between pre-service teachers' use of 21 st Century learner skills and 21st Century teacher skills. Egitim ve Bilim, 42(190), 107-130.

Güler, A., Halıcıoğlu, M. \& Taşğın, S. (2013). Sosyal bilimlerde nitel araştırma yöntemleri. Ankara: Seçkin Yayıncılık.

Haladyna, T. M. (1997). Writing test items to evaluate higher order thinking. Boston: Allyn and Bacon.

Harari, Y.N. (2018). 21.Yüzyıl için 21 ders. Şiral, S. (Çev.), İstanbul: Kolektif Kitap.

Hayırsever, F. \& Kısakürek, M. A. (2014). Sosyal bilgiler ders kitabının, ilköğretim programında kazandırılması hedeflenen beceriler açısından değerlendirilmesi. Uluslararası Eğitim Programları ve Öğretim Çalışmaları Dergisi, 4(8), 23-42. https://doi.org/10.31704/ijocisc8s1.

Herrington, J. \& Kervin, L. (2007). Authentic learning supported by technology: Ten suggestions and cases of integration in classrooms. Educational Media International, 44(3), 219-236. https://doi.org/10.1080/09523980701491666.

Johnson, S. \& Siegel, H. (2010). Teaching thinking: Key debates in educational policy. In C.Winch (Ed.), On thinking skills (113-125). London: UK Continium Press.

Klimova, F. B. (2012). Developing thinking skills in the course of academic writing. Procedia Social and Behavioral Sciences, 93, 505-511. https://doi.org/10.1016/j.sbspro.2013.09.229.

Koçoğlu, E. \& Aydın, M. (2017). Alan uzmanlarına göre 2017 sosyal bilgiler programının 2005 programı çerçevesinde analizi. International Journal of Social Science Research, 6(1), 6174.

Kutlu, Ö., Doğan, C. D. \& Karakaya, İ. (2010). Öğrenci başarısının değerlendirilmesi. Performansa ve portfolyoya dayal durum belirleme. Ankara: Pegem Akademi. https://doi.org/10.14527/9786053647003.

Marzano, R. J. (2001). Designing a new taxonomy of educational objectives. Thousand Oak, California: Corwin Press, Inc.

McGregor, D. (2007). Developing thinking; developing learning. New York, USA: Open University Press.

Memişoğlu, H. \& Köylü, G. (2015). Sosyal bilgiler dersindeki sorunlar ve çözüm yollarına ilişkin sosyal bilgiler öğretmenlerinin görüşleri. Electronic Turkish Studies, 10(11), 1099-1120. https://doi.org/10.7827/turkishstudies.8560.

Milli Eğitim Bakanlığı. (2005). İlköğretim okulları Türkçe dersi (1-5 Sinıflar) öğretim programı. Milli Eğitim Bakanlığı Yayınları, Ankara. https://doi.org/10.1501/egifak_0000000942.

Milli Eğitim Bakanlığı. (2018). Sosyal bilgiler dersi öğretim programı (4-8 Sinıflar). Milli Eğitim Bakanlığı Yayınları, Ankara. https://doi.org/10.1501/egifak_0000000942.

Milli Eğitim Bakanlığı. (2018). Hayat bilgisi dersi ögretim programı (1-3 Sınıflar). Milli Eğitim Bakanlığı Yayınları, Ankara. https://doi.org/10.1501/egifak_0000000942.

Milli Eğitim Bakanlı̆̆ı. (2018). T.C. Inkılap Tarihi ve Atatürkçülük (8. Sinıflar). Milli Eğitim Bakanlığ1 Yayınları, Ankara. https://doi.org/10.1501/egifak_0000000942.

Milli Eğitim Bakanlığı 18 Temmuz 2017 tarihli basın açıklaması. https://ttkb.meb.gov.tr/meb_iys_dosyalar/2017_07/18160003_basin_aciklamasiprogram.pdf 13.10.2019'de erişilmiştir. 
Sosyal Bilgiler Alanı Öğretim Programlarına Ait Kazanımların Zihinsel Beceriler Temelinde... 31

Öztürk, T. (2015). Öğrencilerin hayat bilgisi dersi öğretim programındaki temel becerileri kazanmalarına yönelik öğretmen görüşleri. Eğitim ve Bilim, 40(181), 271-292. https://doi.org/10.18020/kesit.1141.

Öztürk, T. \& Kalafatçı, Ö. (2016). İlkokul hayat bilgisi dersi öğretim programının uygulanabilirliğinin öğretmen görüşlerine göre değerlendirilmesi. Ihlara Eğitim Araştırmaları Dergisi, 1(1), 58-74. https://doi.org/10.15285/maruaebd.525249.

Patton, M. Q. (2014). Nitel araştırma ve değerlendirme yöntemleri. Ankara: Pegem Akademi.

Romizowski, A. J. (1981). Designing instructional systems: decision making in course planning and curriculum design. London: Kogan Page.

Resnick, L. B. (1987). The thinking curriculum. Washington, DC: National Academy Press.

Resnick, L. B. \& Klopfer, L. E. (1989). Toward the thinking curriculum: Current cognitive research (ASCD Yearbook). Alexandria, VA: Association for Supervision and Curriculum Development.

Resnick, L. B. (2010). Nested learning systems for the thinking curriculum. Educational Researcher. 39(3), 183-197. https://doi.org/10.3102/0013189x10364671.

Semerci, N. \& Yelken, T. Y. (2010). İlköğretim programlarındaki ortak temel becerilere ilişkin öğretmen görüşleri (Elazı ̆̆ İli Örneği). Fırat Üniversitesi Doğu Araştırmaları Dergisi, 8(2), 47-54. https://doi.org/10.14686/201211998.

Senemoğlu, N. (2011). College of education students' approaches to learning and study skills. Eğitim ve Bilim, 36(160), 65-80.

Silverman, D. \& Marvasti, A. (2008). Doing qualitative research: A comprehensive guide. Thousand Oaks, CA: Sage.

Tangülü, Z., Tosun, A. \& Kocabıyık, B. (2014). Ortaokul 8. sınıf inkılâp tarihi ve Atatürkçülük konularının öğretiminde karşılaşılan sorunların sosyal bilgiler öğretmen görüşlerine göre değerlendirilmesi. Trakya Üniversitesi Sosyal Bilimler Dergisi, 16(2), 233-245. https://doi.org/10.18069/fusbed.38947.

Taş, H. \& Kıroğlu, K. (2018). 2017 İlkokul sosyal bilgiler dersi öğretim programının öğretmen görüşlerine göre değerlendirilmesi. İlkögretim Online, 17(2), 697-716. https://doi.org/10.17051/ilkonline.2018.419041.

Taşkıran, C. (2014). Altıncı sınıf sosyal bilgiler programındaki kazanımların zihinsel beceriler açısından incelenmesi. Uluslararası Türk Eğitim Bilimleri Dergisi, 2014(2), 1-13. https://doi.org/10.29250/sead.549235.

Tay, B. \& Baş, M. (2016). 2009 ve 2015 Yılı Hayat Bilgisi Dersi Öğretim Programlarının Karşılaştırılması. Bayburt Eğitim Fakültesi Dergisi. 10(2), 341-374. https://doi.org/10.17860/mersinefd.342260.

Tonga, D. \& Uslu, S. (2015). Sosyal bilgiler dersinde kazanım-değer ilişkisi. Journal of Kirsehir Education Faculty, 16(1), 91-110.

Voogt, J. \& Roblin, N. P. (2012). A comparative analysis of international frameworks for $21 \mathrm{st}$ century competences: Implications for national curriculum policies. Journal of Curriculum Studies, 44(3), 299-321. https://doi.org/10.1080/00220272.2012.668938.

Yıldırım, A. \& Şimşek, H. (2011). Sosyal bilimlerde nitel araştırma yöntemleri (8. Tıpkı Basım). Ankara: Seçkin Yayıncılık. 
Ek:1_Kazanım analiz tablosu

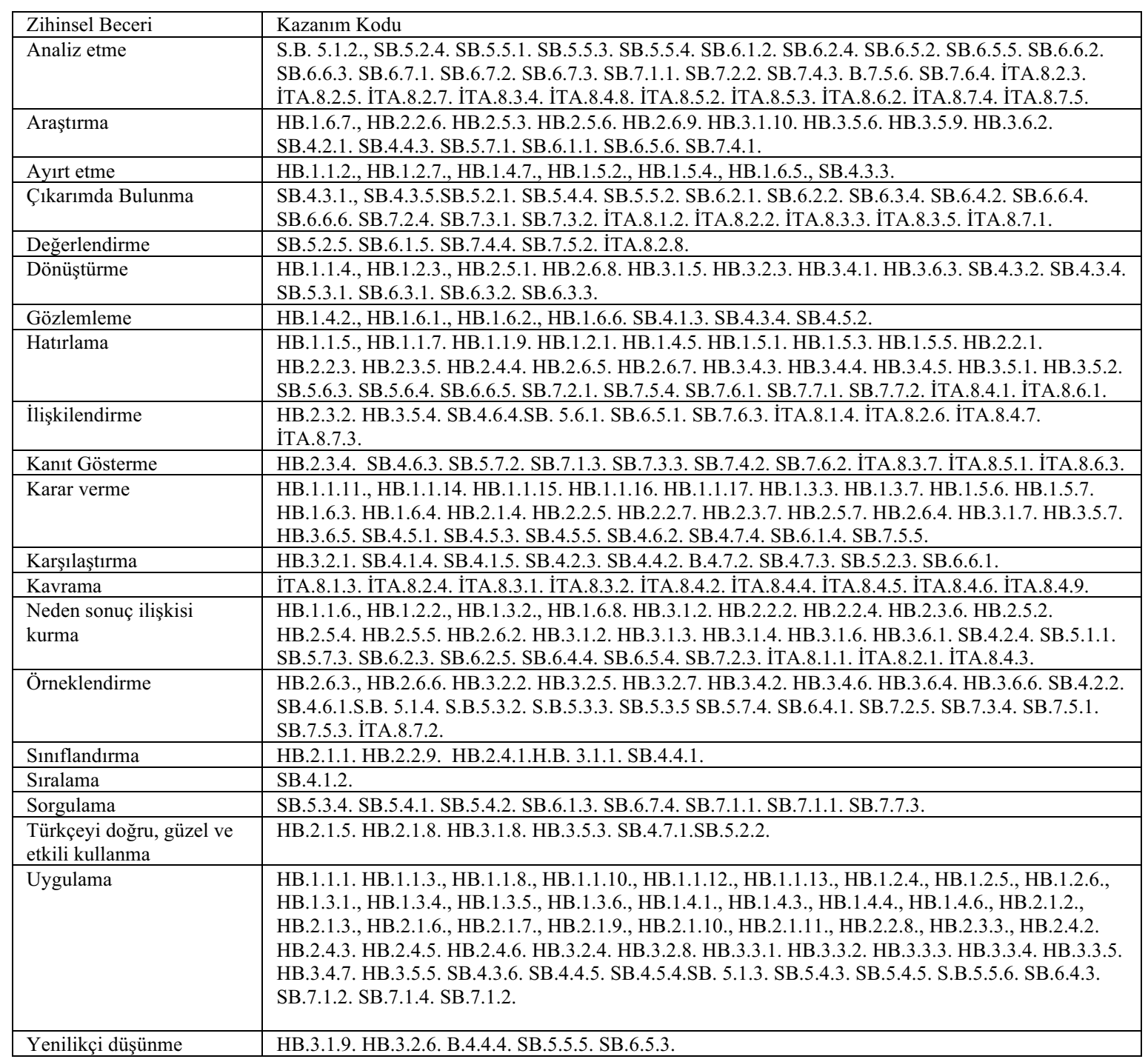

